\title{
CAN LAYER CHICKEN BUSINESS GENERATE INCOME FOR SMALLHOLDER FARMERS IN RURAL AREA OF INDONESIA?
}

\author{
Setiadi Agus*, Santoso Siswanto Imam, Sofyan Ahmad, Mulyono Aditia Dwi, \\ Nurfadillah Suryani, Prayoga Kadhung \\ Department of Agribusiness, Faculty of Animal and Agricultural Sciences, \\ University of Diponegero, Semarang, Central Java, Indonesia \\ *E-mail: agus setiadi2006@yahoo.co.id
}

\begin{abstract}
This study aims were to determine the profitability, economic determinants of laying hens business and income contribution for smallholder laying hens farmer in rural area in Indoesia. Survey study were conducted. 75 laying hens farmers in Kendal regency were chosen as respondent. Kendal area was the highest egg producer in Central java, Indonesia. Respondent was chosen by simple random sampling. The method used in this study was a case study with a quantitative descriptive approach, collecting data using the interview method using a questionnaire and direct observation in the farm. The analytical tools used in this study were $\mathrm{R} / \mathrm{C}$ ratio, BEP price, BEP production, regression analysis and one sample $\mathrm{t}$ test. The results showed that the average ownership of laying hens was 4,233 heads with an average egg production was $5,644 \mathrm{~kg} \mathrm{month}^{-1}$, the average monthly revenue obtained was IDR $98,996,826.00$ and net income per month was IDR $16,418,183, . \mathrm{R} / \mathrm{C}$ ratio of laying hens business was 1.20, BEP price was IDR 14,631 per kg and BEP was 1,740 kg eggs month ${ }^{-1}$. Based on the results of this study, it could be concluded that the farmer's laying business in Kendal Regency was profitable. Feed cost and farm size were siginificantly influenced the income. Reducing feed cost and increasing the farm size increase the laying hens farmer income. Income obtained from laying chicken business was greater than Kendal minimum salary. We can conclude that laying hens business contribute the good income for smallholder farmer in rural area in Indonesia.
\end{abstract}

\section{KEY WORDS}

Profitability, break event point, laying hens, economic determinants, rural area.

The laying chicken industry is growing and is in demand by the community and is considered to have good business opportunities when compared to broilers. The high demand for broiler eggs at the community level and the increase in egg production has made some groups start cultivating laying hens as a business. The background of laying hens is due to an increase in production of broiler eggs in Indonesia from 2015 to 2018 by $16.52 \%$ with an increase in egg consumption an average of $3.57 \%$ or $6.53 \mathrm{~kg} /$ capita / year (Sofyan et al 2019). Animal husbandry is an agricultural sub-sector that is able to influence the conditions of economic stability and inflation in each country. Ekunwe et al (2006) argued that poultry ranks big and important because it is able to bring economic growth very quickly and is able to cover the weaker parts of the economy. Laying hens business could support the food security in rural area.

Livestock business is conducted by many smallholder in rural area in Indonesia. Laying hens business was chosen by smallholder farmer in rural area because easy to handle, and resulted a good income (Sofyan et al, 2019). Ymeri et al (2017) stated beside as a good income egg production also plays important roles on supply protein for community in rural area. Peters et al (2005) stated combination between crop and livstock be able to supply good income for smallholder farmer in rural area. Valbuena et al (2015) stated improving production system lead to improve income of smallholder farmer in rural area. Further they stated improving income from livestock production supply good income, beside their income from crop farmer. In rural area, usually farmer work as crop farmer, beside that farmer also raised livestock as side business. 
Kendal Regency is one of the regions in Central Java with the highest population and production of broiler eggs in Central Java. The population of laying hens in Kendal Regency was $3,799,915$ in 2016 . The laying hens in Kendal Regency are generally people's farms so the population that is cultivated is still low. The livestock population that is kept will affect the amount of revenue and income of a livestock business. According to the research of Malarvizhi and Geeta (2015); Ymeri et al (2017) states that the greater the capacity has an effect on the income and profits obtained. Break-even analysis is used to find out the minimum amount of effort spent either in the calculation of price or from production. So that later can be known advantages or disadvantages experienced by farmers. A business can be said to be profitable and feasible if it is able to have acceptance above 1 (one). The relationship between production costs, revenue and income in laying hens is needed to investigated. This study aims to determine the profitability and economic determinants of laying hens business and income contribution for smallholder laying hens farmer in rural area in Indonesia.

\section{MATERIALS AND METHODS OF RESEARCH}

As shown in Figure 1, this research was carried out in Kendal Regency, where the location was determined by purposive sampling of the District which has the highest potential to produce chicken eggs and has the highest population in Central Java, Indonesia, Location for laying hens business mostly in rural area. Determination of respondents was done by simple random sampling, The farm which has a population of 3000-6000 heads. Sukorejo district was the highest number of laying business in Kendal Regency. 75 (seventy five) laying hens farmer was selected as respondents. The data collection method used in this study was by observation and direct interviews with respondents. The data used in this study consisted of primary and secondary data.

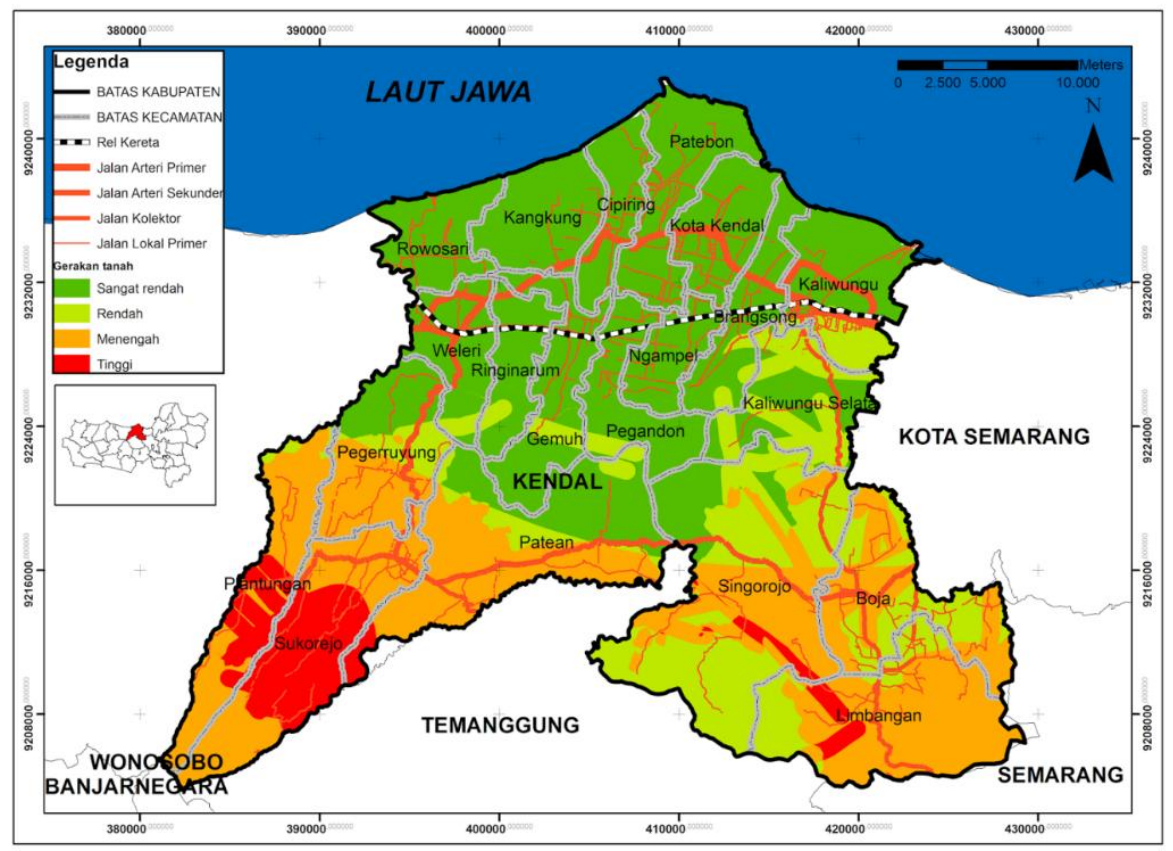

Figure 1 - Study area

Primary data obtained by observing and interviewing directly with respondents with the help of a structured questionaire in accordance with the purpose of the study, while secondary data were obtained from institutions or related agencies such as libraries, Animal Husbandry Office in Kendal Regency, and the Beaureau Central Statistics. Analysis of the data used in this research is qualitative and quantitative analysis. Quantitative analysis used is the analysis of R / C Ratio and Break Even Points. Break Even Point Analysis (BEP = 
Break Event Point) and R / C ratio are calculated based on revenue was obtained and cost spent (Sofyan et al, 2019).

$$
\mathrm{R} / \mathrm{C} \text { ratio }=\mathrm{TR} / \mathrm{TC}
$$

Decision Criteria: R / C $>1$ profitable business; $R$ / $C<1$ business loss; $R$ / $C=1$ breakeven business.

BEP in the unit:

$$
\begin{aligned}
\text { BEP unit } & =F C /(P-V C) \\
\text { BEP in IDR } & =F C /(1-V C / P)
\end{aligned}
$$

Where: $\mathrm{TR}=$ Total Revenue; TC $=$ Total Cost; FC = Fixed Cost; VC = Variable Cost; $\mathrm{P}=$ Price per unit. income.

Regression analysis were determine to effect of economic factor on laying hens farmer

$$
Y=a+b 1 X 1+b 2 X 2+b 3 \times 3+b 4 X 4+e
$$

Where: $Y=$ Income; $a=$ constant; $b 1, b 2, b 3, b 4=$ regression coefficients; $X 1=$ Feed cost; $\mathrm{X} 2=$ Vaccines and medicines cost; $\mathrm{X} 3=$ Labor cost; $\mathrm{X} 4$ = Farm size; $\mathrm{e}=$ error.

One sample t-test was used to compare the income was obtained and Kendal minimum salary.

\section{RESULTS AND DISCUSSION}

Socio-economic characteristics of research respondents. Research respondents have characteristics as presented in Table 1. The average age of respondents who are smallscale laying hens is 46 years. Age affects the experience of farmers and the ability of farmers and the adoption of technology in the world of animal husbandry. The education level of the respondents as many as $14 \%$ were junior high school graduates; $78 \%$ were high school graduates and $8 \%$ was Diploma / undergraduates graduates. Education influences one's thinking and the ability of farmers to receive information and solve problems related to animal husbandry business as well as technical aspects of maintenance. The average experience of raising laying hens from respondents was 11 years. The more experience a farmer has, the better it will be in running a business that can shape one's entrepreneurial spirit for the better.

Table 1 - Socio-economic characteristics

\begin{tabular}{ll}
\hline \hline Respondent characteristics & Value \\
\hline Age (year) & 46 \\
Educational Background (\%) & 14 \\
Junior high School & 78 \\
Senior High School & 8 \\
Diplom/undergraduate & 11 \\
Experiences (year) & 4,233 \\
Scale of ownership (heads) & 268 \\
Egg production $\left(\mathrm{kg} \mathrm{month}^{-1}\right)$ & \\
\hline
\end{tabular}

The ownership scale of laying hens was 4,233 heads with the average egg production was $5,644 \mathrm{~kg} \mathrm{month}^{-1}$, the number of ownership will affect the income of farmers and the profitability of their businesses. The higher the layer of chicken that is cultivated means the business income is above the breakeven point that is attempted (Nmadu et al 2014; Roy 2017).

Production costs in the laying hens business are divided into two, namely fixed costs consisting of depreciation and electricity and water payment costs. Variable costs consist of 
feed costs, vaccine and medicines cost and labor costs, the number and percentage of production costs presented in Table 2 .

The average fixed costs per month was IDR $9,067,800$ or contributes $11.64 \%$ of the total production costs. The average variable costs was IDR $72,970,843.00$ or $88.36 \%$ production costs come from variable costs. The percentage of feed costs in production costs occupies the largest percentage when compared with other cost components which reach $84.61 \%$. Feed costs in laying hens business was $70 \%$ of all production costs and in variable costs accounted for the largest percentage compared to other costs (Bose et al 2015; Nmadu et al 2014; Odimegwe et al 2015)

Table 2 - Production cost of laying hens business

\begin{tabular}{lll}
\hline \hline Items & Cost $\left(\right.$ IDR month $\left.{ }^{-1}\right)$ & Percentages (\%) \\
\hline Fixed cost & & \\
Electricity and water & 739,500 & 0.90 \\
Depreciation & $8,868,300$ & 10.74 \\
Sub Total & $9,607.800$ & \\
Variable cost & & 84.61 \\
Feed & $69,868,560$ & 0.94 \\
Vaccines and Medicines & 774,117 & 2.81 \\
Labor & $2,328,167$ & 100 \\
Sub Total & $72,970,843$ & \\
Production cost & $82,578,643$ & \\
\hline
\end{tabular}

Revenue from laying hens is obtained from sale of fresh eggs was IDR 98,996,827 per month. The selling price of eggs per $\mathrm{kg}$ from farmers was IDR. 18,000 with an average egg production per month was $5,644 \mathrm{~kg}$ of fresh eggs. The amount of revenue depends on the number of chickens that produce in a cage and the amount of costs incurred in laying hens. Ayinde et al (2012); Anang et al (2013) stated that the number of chickens in a cage had a significant effect on egg production, egg sales and the sale of culling chickens impacted on farmer income.

The total income obtained from total revenue is reduced by the total cost in a production. The net income from laying hens in one month of production can be seen clearly the remainder of the sale of fresh eggs for one month reduced by the production costs incurred by farmers. The production cost, revenue, income and $\mathrm{R} / \mathrm{C}$ ratio are presented in Table 3. The average income per month was IDR 16,418,184.00. Revenue is affected by number of egg sold, the greater the volume of egg sales and the lower production costs, the higher the income earned.

$\mathrm{R}$ / C ratio value of laying hens was 1.20, presented in Table 3. $\mathrm{R}$ / $\mathrm{C}$ ratio of more than 1 then the business was declared profitable or feasible to be developed then it can be explained that every earn IDR $1,000,000$ would received IDR $1,200,000$. This indicates that the business of laying hens was profitable. The $\mathrm{R} / \mathrm{C}$ ratio values obtained was profitable (Eryanti et al 2016; Emokaro and Erhabor 2014).

Table 3 - Production cost, revenue, income and R/C ratio laying hens business

\begin{tabular}{cc}
\hline \hline Items & Value (IDR month ${ }^{-1}$ ) \\
\hline Revenue & $98,996,827$ \\
Production cost & $82,578,643$ \\
Income & $16,418,184$ \\
R/C ratio & 1.20 \\
\hline
\end{tabular}

Break even point analysis could inform the level of sales volume, as well as its relationship with the possibility of making a profit according to the level of sales concerned. Calculation of Break Even Point in laying hens, there are two, namely calculating the break even point of the price of whole eggs and calculating the break even point of the results of whole eggs in units of kilograms.

BEP for egg production per month as indicated in Table 4 was $1,740 \mathrm{~kg}$, the average production yield per month was $5,644 \mathrm{~kg}$, the value of fresh egg production is higher when 
compared to the results of calculations, as well as the Break Even Point at the selling price where the selling price actually higher at IDR. 18,000.00 when compared to the Break Even Point calculation was IDR 14,631. The existence of a margin on the selling price and production with the value of the Break Even Point calculation indicates that there was a profit that can be taken in a business (Deze et al 2010; Niu et al 2016; Roy 2017).

Table 4 - Breakeven point and egg production laying hens business

\begin{tabular}{|c|c|c|}
\hline No. & Items & Value \\
\hline 1 & Scale of ownership (heads) & 4,233 \\
\hline 2 & Egg production ( $\mathrm{kg}$ month ${ }^{-1}$ ) & 5,644 \\
\hline 3 & Fixed cost IDR month ${ }^{-1}$ ) & $9,607,800$ \\
\hline 4 & Variable cost (IDR month ${ }^{-1}$ ) & $70,642,676.67$ \\
\hline 5 & Egg price (IDR kg ${ }^{-1}$ ) & 18,000 \\
\hline 6 & Revenue (IDR month ${ }^{-1}$ ) & $98,996,827$ \\
\hline 7 & Income (IDR month ${ }^{-1}$ ) & $16,418,183$ \\
\hline 8 & Egg production BEP (kg month $\left.{ }^{-1}\right)$ & 1,740 \\
\hline 9 & Egg price BEP (IDR kg ${ }^{-1}$ ) & 14,631 \\
\hline
\end{tabular}

Economic determinants of laying hens farmer income. As shown in table 5, Feed cost, and farm size influenced the income significantly $(P<0.05)$. The increasing of feed cost would decreased the income. Increasing farm size would increase the income. Effort to looking low cost feed is neede to improve the income. Farmer also Vaccine and medicines cost and labor cost not statistically $(P>0.05)$ influenced the income. This condition might be vaccines and medicies cost and labor cost were low so not statistically influenced the income. This results in agreement with Sofyan study (2019) which stated that economic factor influenced significantly $(\mathrm{P}<0.05)$ on income.

Table 5 - Economic determinants of laying hens' farmer

\begin{tabular}{lllll}
\hline \hline No & Items & Coefficients & SE & P Values \\
\hline 1 & Constant & -2.378 & 0.13 & 0.007 \\
2 & Feed cost & -6598.70 & 0.776 & 0.002 \\
3 & Vaccines and medicines cost & -76.85 & 0.376 & 0.632 \\
4 & Labor cost & -776 & 0.980 & 0.075 \\
5 & Farm size & 485 & 1.76 & 0.009 \\
\hline
\end{tabular}

Income was obtained by laying hen farmer was IDR $28,354,151$ (Table 1 ). The income was greater than Kendal minimum salary was IDR 2,200,000. $(P<0.05)$. tis result indicated that laying hens potensial developed in rural area because of income source potential.

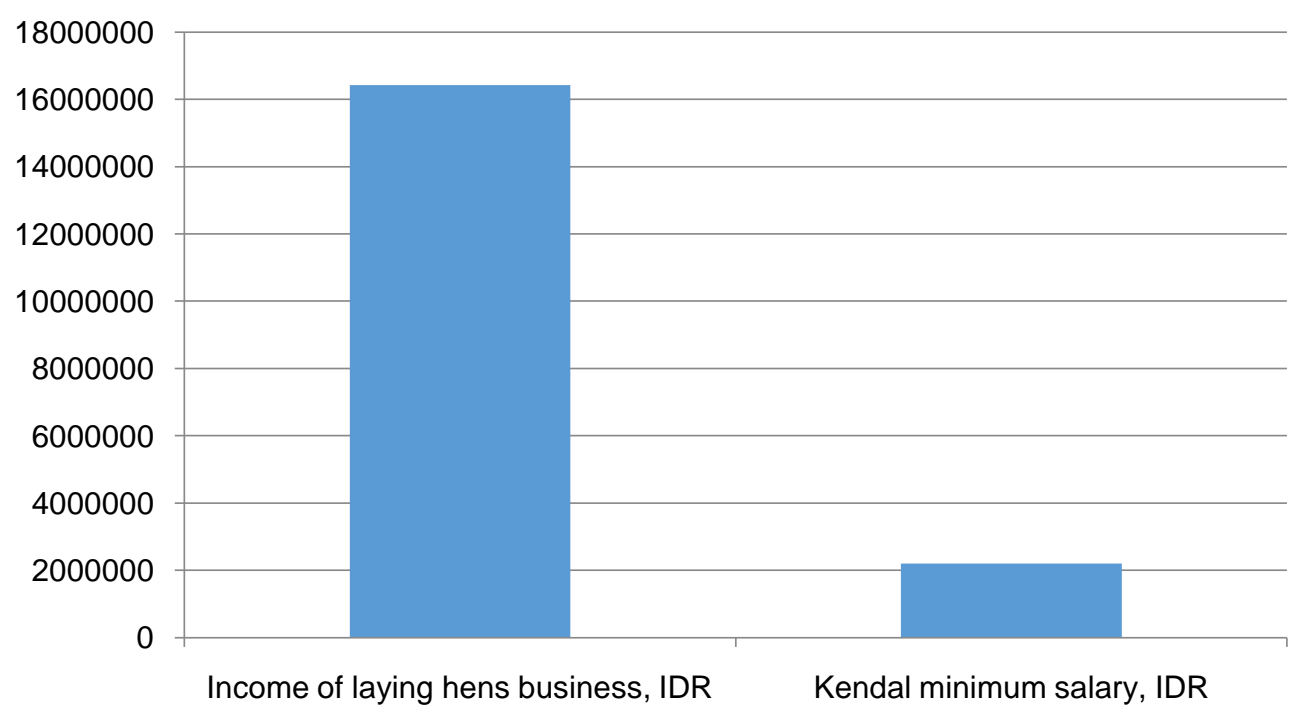

Figure 2 - Comparison between income laying hens business and Kendal minimum salary 
As presented in figure 2, laying hens business resulted high income compared with Kendal minimum salary. This condition indicated laying hens business play important role in rural area in Indonesia, laying hens business contribute $77.38 \%$ from the smallholder income (Figure 3).

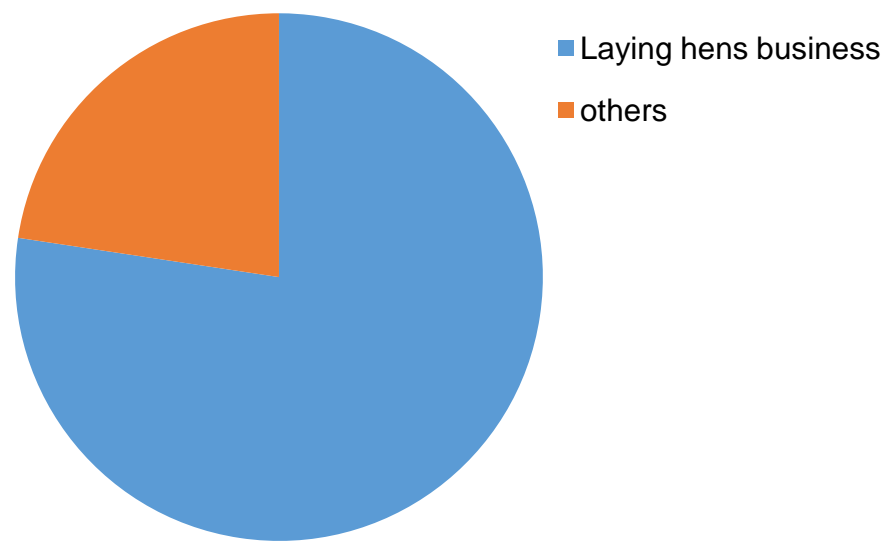

Figure 3 - Income contribution of laying hens business to total income

Laying hens business contributed high income of smallholder total income. This business resulted high income compared with Kendal minimum salary. Laying hens business contribute the rural development in Indonesia, because the business resulted $77.38 \%$ from total income. Laying hens business was the main job for smallholder farmer in rural area in Indonesia. This result in agreement with Peters et al (2015) livestock production would support the welfare of smallholder farmer in rural area.

\section{CONCLUSION}

Based on the results of the above study it can be concluded that the average ownership of laying hens in Kendal Regency was 4,233 heads with egg production per month was $5,644 \mathrm{~kg}$. Revenues and income of laying hens business per month were IDR $98,996,827.00$ and IDR16,418,184.00 with an R/C ratio of 1.20 . BEP value of egg production per month was $1,740 \mathrm{~kg}$ and BEP selling price of eggs was IDR 14,631. Laying chicken farms in Kendal Regency was profitable. Feed cost and farm size influenced the income laying hens farmer significantly. Laying hens business contribute $77.38 \%$ of total income. This indicated laying hens business contributed good income for smallholder in rural area in Indonesia.

\section{REFERENCES}

1. Anang B. T., C. Yeboah, A. A. Agbolosu., 2013. Profitability of broiler and layer production in the brong ahafo region of Ghana. J. Agric. Biol. Sci. 8(5): 423-430.

2. Ayinde I. A., S. B. Ibrahim, S. O. Arowolo., 2012. Economics of poultry egg production under two management systems in Ogun State, Nigeria. Nigerian J. Agric. Economic 3(1): 40-49.

3. Bose A. A., Abba I. Y., Madaki M. J., Obute O. L., 2015. Analysis of poultry (layers) enterprises in Igabi Local Government Area, Kaduna State Nigeria. J. of Agric and Veterinary Sci. 8(4): 43-49.

4. Deze J., L. Ranogajec, A. Crncan, J. Kristic., 2010. Break-even analysis (bea) in egg production. Poljoprivreda 16(2): 47-50.

5. Ekunwe P. A., O. O. Soniregun, J. O. Oyedeji., 2006. Economics of Small Scale Deep Litter System of Egg Production in Oredo Local Government Area of Edo State Nigeria. Int. J. Poult. Sci. 5(1): 81-83. 
6. Emokaro C. O., P. O. Erhabor., 2014. Comparative Analysis of Profitability of Layers Production in Esan North East and Ovia North East Local Government Areas of Edo State, Nigeria. J. Appl. Sci. Environ. Manage. 18(1): 121-126.

7. Girei A. A., S. B. Ohen, N. D. Saingbe, A. Habila., 2018. Costs and Return Analysis in Poultry Egg Production in Lafia Local Government Area (LGA) of Nasarawa State, Nigeria. Asian J. Agric. Exten. Econ. Socio. 24(1): 1-10.

8. Malarvizhi V., K. T. Geetha., 2015. Economic cost \& profit assessment of poultry farming in Namakkal District. J. Manage. and Sci. 5(2):42-55.

9. Memon I. N., S. Noonari, M. Asif, S. T. Shah, M. B. Peerzado, G. M. Panhwar, A. A. Sethar, G. Y. Kalwar, M. A. Bhatti, A. S. Jamro., 2015. Economic Analysis of Poultry Egg Production in Quetta District Balochistan. J. Fisheries Livest Prod. 3(3): 1-7.

10. Nawawi A. M., S. A. Andayani, Dinar., 2017. Business analysis of layer farm (Case study Layer Farm Cihaur, Maja, Majalengka, West Java). J. IImu Pertanian and Peternakan 5(1): 15-29.

11. Niu E., H. Saediman, Surni., 2016. Break even analysis of poultry egg production in rural area in Southeast Sulawesi. Binus Business Review 7(3): 227-232.

12. Nmadu J. N., I. O. Ogidan, R. A. Omolehin., 2014. Profitability and Resource Use Efficiency of Poultry Egg Productionin Abuja, Nigeria. J. Soc. Sci. 35: 134-146.

13. Odimegwe F. E., O. W. Babatunde, O. Festus, A. Sunday., 2015. Assessment of the profitability of poultry egg farming in Ogun State, Nigeria. Afrian J. Poult. Farming 3(4): 092-096.

14. Peters, D., N. T. Tinh., M. T. Hoan., Nguyen The Yen., Pham Ngoc Thach and K. Fuglie. 2005. Rural income generation through improving crop-based pig production systems in Vietnam: Diagnostics, interventions, and dissemination. Agriculture and Human Values 22: 73-85

15. Roy A., 2017. Economic and profitability potential assessment of poultry farming in West Bengal. Indian J. Poult. Sci. 52(3): 343-346.

16. Sofyan A., E. Suprijatna, S. I. Santoso, A. Setiadi., 2019. Business sustainability model of smallholder layer farms in Kendal Regency, Central Java, Indonesia. Journal of the Indonesian Tropical Animal Agriculture 44(4): 408-414.

17. Valbuena, D Jeroen., C. J. Groot Diego., J.Mukalama., B. Ge 'rard and P. Tittonell. 2015. Improving rural livelihoods as a "moving target": trajectories of change in smallholder farming systems of Western Kenya. Reg Environ Change 15:1395-1407

18. Ymeri P., F. Sahiti, A. Musliu, F. Shaqiri, M. Pllana., 2017. The effect of farm size on profi tability of laying poultry farms in Kosovo. Bulg. J. Agric. Sci. 23(3): 376-380. 